\title{
Manajemen Risiko Keamanan Aset Teknologi Informasi Menggunakan ISO 31000:2018 Diskominfo Kota Salatiga
}

\author{
Muhammad Ilham Fachrezi*1, Ariya Dwika Cahyono ${ }^{2}$, Penidas Fiodinggo Tanaem ${ }^{3}$ \\ ${ }^{1,2}$ Universitas Kristen Satya Wacana; Jl. Diponegoro No.52-60, Salatiga, Kec. Sidorejo, Kota Salatiga, \\ Jawa Tengah 50711, (0298) 321212 \\ ${ }^{3}$ Jurusan Sistem Informasi, FTI UKSW, Salatiga \\ e-mail: *11 fachrezilhm@gmail.com, ${ }^{2}$ ariyadc@uksw.edu, ${ }^{3}$ penidas.fiodinggo@uksw.edu
}

\begin{abstract}
Abstrak
Dinas Komunikasi dan Informatika (DISKOMINFO) Kota Salatiga merupakan instansi pemerintah yang menggunakan teknologi informasi sebagai peranan penting untuk menunjang proses bisnis. Untuk itu, perlu adanya manajemen risiko sebagai standar atau pedoman dalam penanganan dan perlindungan terhadap aset teknologi informasi. Tujuan dari penelitian ini untuk mengidentifikasi, menganalisis dan mengelola risiko keamanan aset teknologi informasi dan juga mengetahui tingkat risiko pada aspek keamanan aset teknologi informasi. Penerapan manajemen risiko pada penelitian ini menggunakan ISO 31000:2018 yang terdiri dari tahap identifikasi risiko, tahap analisis risiko, tahap evaluasi risiko, dan tahap perlakuan risiko. Dari hasil penelitian ini, terdapat 2 kemungkinan risiko dengan tingkatan rendah, 11 kemungkinan risiko dengan tingkatan menengah, dan 4 risiko tingkat tinggi. Dari hasil tersebut, maka DISKOMINFO Kota Salatiga memerlukan perhatian khusus pada permasalahan listrik yang sering padam, server down, koneksi internet yang sering putus, dan sambaran petir.
\end{abstract}

Kata $\mathbf{k u n c i}$ - manajemen risiko, teknologi informasi, analisis risiko, penilaian risiko.

\section{Abstract}

The Office of Communication and Information Technology (DISKOMINFO) Salatiga City is a government agency that uses information technology as an important role to support business processes. For this reason, it is necessary to have risk management as a standard or guide in the handling and protection of information technology assets. The purpose of this study is to identify, analyze and manage the security risks of information technology assets and also to determine the level of risk in the security aspects of information technology assets. The application of risk management in this study uses ISO 31000: 2018 which consists of the risk identification stage, the risk analysis stage, the risk evaluation stage, and the risk treatment stage. From the results of this study, there are 2 possible low-level risks, 11 medium-level possible risks, and 4 high-level risks. From these results, DISKOMINFO Salatiga City requires special attention to the problems of frequent power outages, servers down, internet connection that often breaks, and lightning strikes.

Keywords — risk management, information technology, risk analysis, risk assessment.

\section{PENDAHULUAN}

Dinas Komunikasi dan Informatika (DISKOMINFO) Kota Salatiga Provinsi Jawa Tengah yang berada di Jalan Letjend Sukowati No. 51 merupakan instansi pemerintahan yang memiliki tugas untuk melaksanakan urusan pemerintahan yang menjadi kewenangan Daerah dalam 
bidang komunikasi dan informatika, bidang statistik dan bidang persandian serta tugas pembantuan yang diberikan kepada Daerah.

Dalam melaksanakan tugas dengan didukungnya teknologi informasi pada dinas tersebut, aset teknologi informasi memiliki peranan penting untuk berjalannya proses bisnis DISKOMINFO Kota Salatiga karena aset teknologi informasi merupakan salah satu sarana sumber informasi penting pada DISKOMINFO Kota Salatiga. Jika aset teknologi informasi mendapat ancaman dan serangan baik dari dalam maupun dari luar maka dapat menimbulkan risiko yang mengganggu dalam proses bisnis bahkan juga dapat menghentikan proses bisnis[1]. Oleh karena itu, begitu pentingnya manajemen risiko sebagai penanganan dan perlindungan terhadap aset dengan cara melakukan penilaian risiko untuk menindaklanjuti perlakuan risiko yang telah diberikan guna meminimalisir risiko-risiko yang mungkin terjadi di DISKOMINFO Kota Salatiga.

Untuk mengetahui nilai risiko pada aset teknologi informasi di DISKOMINFO Kota Salatiga, maka digunakanlah ISO (International Organization for Standardization) 31000:2018 Risk Management - Guideline. ISO 31000:2018 yang merupakan sebuah standar atau pedoman manajemen risiko memiliki tiga elemen yaitu prinsip, kerangka kerja, dan proses. Prinsip pada manajemen risiko adalah filosofi manajemen risiko sedangkan kerangka kerja adalah pengaturan yang terstruktur dan sistematis pada sistem manajemen risiko dan untuk proses adalah aktivitas dalam pengelolaan risiko secara berurutan dan saling berhubungan satu dengan yang lain[2].

ISO 31000:2018 resmi dirilis pada Februari 2018 yang menggantikan ISO 31000:2009 Risk Management - Principles and Guideline[2]. ISO 31000:2018 dirilis untuk memastikan tetap relevan sesuai dengan evolusi pasar dan tantangan baru yang dihadapi oleh organisasi[3]. Selain itu, ISO 31000:2018 juga memberikan pedoman yang lebih strategis dan lebih menekankan keterlibatan manajemen senior dan integrasi manajemen risiko dalam organisasi.

\section{METODE PENELITIAN}

\subsection{Penelitian Terdahulu}

Penelitian sebelumnya yang berkaitan dengan ISO 31000 dilakukan di Dinas Komunikasi, Informatika, Persandian dan Statistik (DISKOMINFOPS) Kabupaten Indragiri Hilir Kota Tembalang Provinsi Riau pada tahun 2019 oleh Reski Mai Candra. Penelitian ini membangun sistem manajemen risiko keamanan aset teknologi informasi berdasarkan pedoman ISO 31000:2018. Dalam penelitian ini ditemukan adanya 45 risiko yang teridentifikasi dengan 14 risiko level rendah, 16 risiko level menengah, dan 15 risiko level tinggi [1].

Penelitian lain yang berkaitan dengan ISO 31000 dilakukan di PT. Remaja Rosdakarya pada tahun 2018 oleh Tri Ramdhany dan Rio Andriyat Krisdiawan dengan judul "Analisis risiko sistem informasi penjualan pada PT. Remaja Rosdakarya menggunakan ISO 31000". Hasil dari penelitian ini adalah analisis nilai risiko dan nilai dampak yang muncul pada sistem informasi penjualan sesuai dengan standar ISO 31000. Dengan adanya analisis risiko tersebut dapat mengurangi dampak negative melalui perlakuan risiko dan juga dapat membantu dalam para pemangku jabatan terkait dalam mengambil keputusan lebih baik [4].

Selain penelitian di atas, penelitian yang meggunakan ISO 31000 adalah "Analisis Manajemen Risiko Menggunakan ISO 31000 pada Smart Canteen SMA XYZ” oleh Dewangga Lazuardi Ramadhan pada tahun 2020. Hasil dari penelitian yang diperoleh dari proses evaluasi risiko menggunakan table matriks ditemukan 1 nilai risiko ekstrim, 2 nilai risiko tinggi, 4 nilai risiko sedang, dan 5 nilai risiko rendah. Dengan adanya penelitian ini diharapkan dapat mengurangi risiko yang timbul pada Smart Canteen SMA XYZ [5]. 


\section{2 Landasan Teori}

\section{2.1 Risiko}

Risiko adalah sebuah ketidakpastian pada masa yang akan datang dan mempunyai dampak negatif terhadap tujuan yang ingin dicapai [2]. Adanya risiko merupakan sebuah tantangan bagi organisasi, karena dalam menimimalisir terjadinya risiko perlu adanya manajemen risiko dengan baik. Manajemen risiko diperlukan untuk melindungi aset yang dimiliki organisasi dan untuk mengelola risiko menjadi sebuah peluang bagi organisasi. Agar terjamin keefektivitasnya pada suatu perusahaan, manajemen risiko harus memenuhi prinsip dan pedoman yang sudah ditentukan [6].

\section{2.2 Framework ISO 31000:2018}

ISO 31000 adalah sebuah panduan atau pedoman dalam melakukan penerapan risiko yang dikodifikasi oleh International Organization for Standardization (ISO). Tujuan ISO 31000 adalah sebagai standar internasional untuk penerapan manajemen risiko yang dapat digunakan oleh berbagai jenis organisasi dalam menghadapi berbagai risiko yang ada pada proses bisnis organisasi [3]. Dalam proses manajemen risikonya, ISO 31000 membagi kriteria risiko berdasarkan tingkat kepentingannya [6]. ISO 31000:2018 menggantikan versi 2009 yang merubah nama dari "principles and guidelines" menjadi "guidelines". Hal ini merupakan penyederhanaan dari versi sebelumnya, telihat dari jumlah halaman yang berkurang dari 24 halaman menjadi hanya 16 halaman [2].

\section{3 Metodologi Penelitian}

Metode penelitian adalah tahap dalam melakukan proses penelitian agar hasil penelitian yang telah tercapai sesuai dengan apa yang diinginkan. ISO 31000 yang merupakan standar manajamen risiko dengan tujuan untuk memberikan prinsip-prinsip dan pedoman dalam melakukan manajemen risiko. Berikut adalah tahap-tahap proses manajemen risiko secara garis besar:

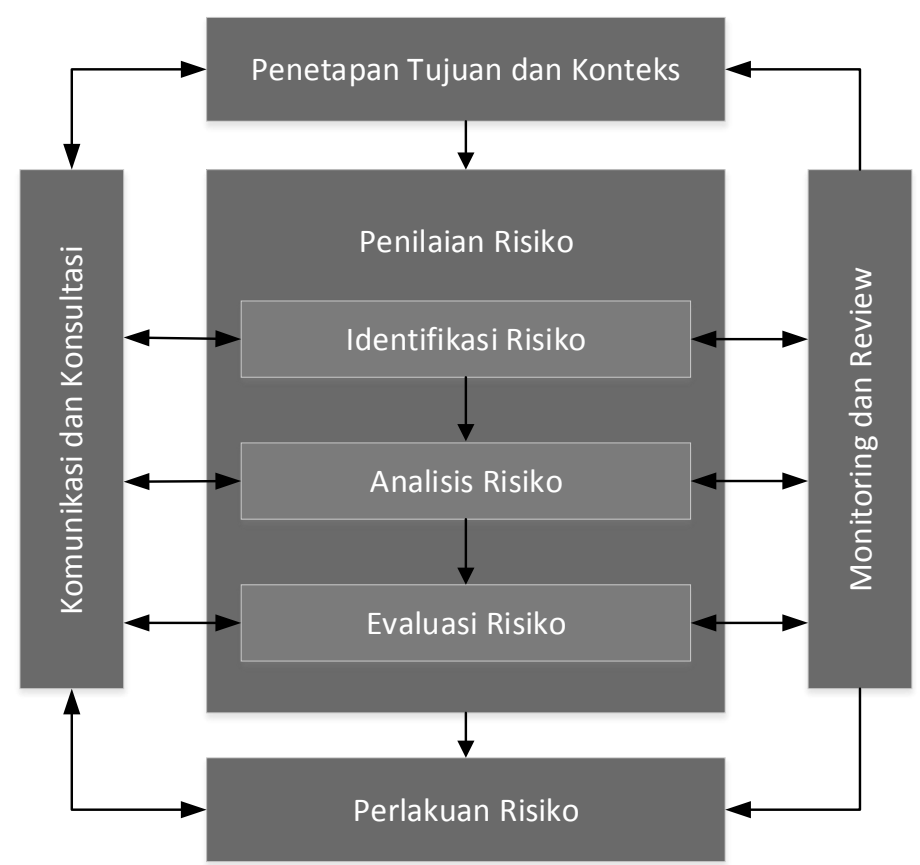

Gambar 1. Tahap Penelitian

Fachrezi, et., al [Manajemen Risiko Keamanan Aset Teknologi Informasi Menggunakan Iso 31000:2018 Diskominfo Kota Salatiga] 


\section{3.1 Komunikasi dan Konsultasi}

Tujuan tahap komunikasi dan konsultasi adalah untuk membantu pemangku kepentingan dalam memahami risiko, pengambilan keputusan dan perlakuan terhadap risiko yang ada. Oleh karena itu, tahap komunikasi dan konsultasi adalah tahap yang penting dan diharapkan dapat menjadikan dukungan pada proses manajemen risiko agar proses manajemen risiko menjadi tepat sasaran.

\section{3.2 Penetapan Tujuan dan Konteks}

Pada tahap ini, harus ditentukan tujuan, ruang lingkup dan bagian organisasi apa yang akan dilakukan manajemen risiko. Terdapat empat konteks yang perlu ditentukan dalam tahap ini yaitu konteks internal, konteks eksternal, konteks manajemen risiko, dan konteks kriteria risiko.

\section{3.3 Penilaian Risiko}

Tahap ini bertujuan untuk mengidentifikasi risiko aset teknologi informasi dengan mengetahui kemungkinan terjadinya suatu risiko dan dampak nya terhadap aset teknologi informasi pada DISKOMINFO Kota Salatiga sehingga dapat dihitung berdasarkan matriks manajemen risiko untuk mengetahui apakah risiko aset tersebut dalam kategori rendah, menegah ataupun tinggi. Proses ini terdiri dari 3 tahapan yaitu:

\section{3.3.1 Identifikasi Risiko}

Tujuan dari identifikasi risiko adalah untuk menemukan, mengenali, dan mendeskripsikan risiko berdasarkan informasi yang didapat. Informasi yang relevan dan sesuai penting dalam melakukan identifikasi risiko.

\section{3.3.2 Analisis Risiko}

Tahap ini merupakan tahap menentukan status risiko kedalam peringkat frekuensi kemungkinan [7]. Tujuan dari analisis risiko adalah untuk memahami sifat risiko dan karakteristik risiko [8]. Analisis risiko dapat dilakukan dengan berbagai tingkat detail dan kompleksitas tergantung pada tujuan analisis dan ketersediaan informasi.

\section{3.3.3 Evaluasi Risiko}

Pada tahap ini melibatkan perbandingan hasil analisis risiko dengan kriteria risiko yang sudah ditetapkan. Tujuan dari tahap ini adalah untuk mengetahui tinggi rendahnya prioritas risiko yang ada dan tingkat risiko mana yang harus ditindaklanjuti [9].

\section{3.3.4 Perlakuan Risiko}

Tahap ini merupakan proses menyeleksi dan menerapkan langkah-langkah dalam meminimalisir kemungkinan terjadinya risiko. Tujuan dari perlakuan risiko adalah untuk memilih dan menerapkan tindakan untuk menangani risiko.

\section{3.3.5 Monitoring dan Review}

Tahap ini harus menjadi bagian dari rencana proses manajemen risiko. Tujuan dari tahap ini adalah memastikan bahwa pelaksanaan manajemen risiko berjalan sesuai dengan rencana. Hasil dari tahap monitoring dan review digunakan sebagai bahan pertimbangan akan perkembangan dalam proses manajemen risiko. 


\section{HASIL DAN PEMBAHASAN}

\subsection{Identifikasi Risiko}

Tahap identifikasi risiko ini bertujuan untuk menemukan, mengenali dan mendeskripsikan kemungkinan risiko yang telah didapat melalui proses wawancara. Proses wawancara dilakukan dengan beberapa narasumber yang bertanggung jawab mengenai bidangnya. Berikut rincian beberapa kemungkinan risiko yang dapat dilihat pada Tabel 1 di bawah ini:

Tabel 1. Kemungkinan Risiko

\begin{tabular}{|c|l|}
\hline No & Kemungkinan Risiko \\
\hline 1 & Kerusakan pada hardware \\
\hline 2 & Overheat \\
\hline 3 & Overload \\
\hline 4 & Listrik padam \\
\hline 5 & Server down \\
\hline 6 & Koneksi internet terputus \\
\hline 7 & Kehilangan data \\
\hline 8 & Kesalahan pegawai / Human Error \\
\hline 9 & Dokumentasi program kurang lengkap \\
\hline 10 & Maintenance tidak terjadwal \\
\hline 11 & Serangan virus \\
\hline 12 & Penyalahgunaan hak akses \\
\hline 13 & Pencurian perangkat \\
\hline 14 & Kebakaran \\
\hline 15 & Sambaran petir \\
\hline 16 & Banjir \\
\hline 17 & CCTV tidak berfungsi dengan baik \\
\hline 18 & Genset tidak berfungsi dengan baik \\
\hline
\end{tabular}

\subsection{Analisis Risiko}

Analisis risiko adalah tahap memahami risiko lebih dalam. Artinya, tahap ini menentukan status risiko kedalam peringkat frekuensi kejadian. Analisis risiko dapat menjadikan strategi dalam pengambilan keputusan mengenai kemungkinan risiko yang akan terjadi. Pada DISKOMINFO Kota Salatiga sendiri terdapat beberapa temuan risiko yang dikhawatirkan akan terjadi. Adapun temuan risiko yang sering terjadi hingga mengganggu berjalannya proses bisnis IT yang ada di DISKOMINFO Kota Salatiga.

Risiko pertama adalah gangguan listrik, listrik padam tentu berdampak pada hardware dan server yang akan mengalami down. Jika server down, maka akan mengganggu websitewebsite yang dikelola oleh DISKOMINFO Kota Salatiga. Resiko kedua adalah kurangnya Sumber Daya Manusia yang ada. Karena di DISKOMINFO Kota Salatiga tidak hanya menangani bidang TI di tingkat OPD saja, namun juga menangani seluruh Kota Salatiga seperti internet, Data Center, dan pengembangan aplikasi. Tidak hanya itu, jika pegawai DISKOMINFO Kota Salatiga berhalangan untuk hadir tentu akan berimbas pada layanan yang akan terganggu . Adapun risiko yang dikhawatirkan oleh DISKOMINFO Kota Salatiga yaitu bencana alam terutama gempa bumi. Karena tidak ada server backup yang berbeda lokasi dengan server utama, sehingga jika risiko ini terjadi dapat disimpulkan bahwa data dan layanan akan mengalami gangguan bahkan akan membuat proses bisnis terhenti.

Fachrezi, et., al [Manajemen Risiko Keamanan Aset Teknologi Informasi Menggunakan Iso 31000:2018 Diskominfo Kota Salatiga] 
Dalam penilaian kemungkinan risiko, dilakukan dengan memberikan nilai frekuensi dari 1 sampai 5, semakin besar nilainya maka semakin sering terjadi risiko dan semakin besar dampak yang akan ditimbulkan. Berikut adalah tabel kemungkinan frekuensi kejadian dan tabel penilaian dampak:

Tabel 2. Kemungkinan Frekuensi Kejadian

\begin{tabular}{|c|l|l|}
\hline Frekuensi & Kategori & Keterangan \\
\hline 1 & Sangat kecil & $\begin{array}{l}\text { Kecil kemungkinan terjadi / tidak pernah } \\
\text { terjadi }>5 \text { tahun }\end{array}$ \\
\hline 2 & Kecil & Risiko jarang terjadi 3-5 tahun \\
\hline 3 & Sedang & Risiko terkadang terjadi pada 2-4 tahun \\
\hline 4 & Berat & Risiko sering terjadi 1-2 tahun \\
\hline 5 & Sangat berat & Risiko pasti terjadi < 1 tahun \\
\hline
\end{tabular}

Tabel 3. Penilaian Dampak

\begin{tabular}{|c|l|}
\hline Nilai & Keterangan \\
\hline 1 & Risiko tidak mengganggu aktivitas proses bisnis \\
\hline 2 & Risiko sedikit menghambat proses bisnis \\
\hline 3 & Risiko mengganggu proses bisnis \\
\hline 4 & Risiko menghambat bagian tertentu proses bisnis \\
\hline 5 & Risiko menghambat serta mengganggu seluruh proses bisnis \\
\hline
\end{tabular}

Berikut adalah tabel analisa risiko dengan nilai kemungkinan frekuensi kejadian dan dampak pada masing-masing risiko yang ada:

Tabel 4. Hasil Penelitian Frekuensi dan Dampak

\begin{tabular}{|c|l|c|c|}
\hline No & \multicolumn{1}{|c|}{ Kemungkinan Risiko } & Frekuensi & Dampak \\
\hline 1 & Kerusakan pada hardware & 2 & 3 \\
\hline 2 & Overheat & 2 & 3 \\
\hline 3 & Overload & 3 & 4 \\
\hline 4 & Listrik padam & 5 & 5 \\
\hline 5 & Server down & 5 & 4 \\
\hline 6 & Koneksi internet terputus & 5 & 4 \\
\hline 7 & Kehilangan data & 1 & 5 \\
\hline 8 & Kesalahan pegawai / Human Error & 2 & 3 \\
\hline 9 & Dokumentasi program kurang lengkap & 2 & 4 \\
\hline 10 & Maintenance tidak terjadwal & 1 & 2 \\
\hline 11 & Serangan virus & 2 & 3 \\
\hline 12 & Penyalahgunaan hak akses & 1 & 4 \\
\hline 13 & Pencurian perangkat & 1 & 4 \\
\hline 14 & Kebakaran & 2 & 5 \\
\hline 15 & Sambaran petir & 1 & 5 \\
\hline 16 & Banjir & 2 & 2 \\
\hline 17 & CCTV tidak berfungsi dengan baik & 2 & 5 \\
\hline 18 & Genset tidak berfungsi dengan baik & & \\
\hline
\end{tabular}

\subsection{Evaluasi Risiko}

Pada tahap ini melibatkan perbandingan hasil analisis risiko dengan kriteria risiko yang sudah ditetapkan. Tujuan dari tahap ini adalah untuk mengetahui tinggi rendahnya prioritas risiko. Berikut adalah tabel evaluasi risiko: 
Tabel 5. Evaluasi Risiko

\begin{tabular}{|c|l|c|c|l|}
\hline No & Kemungkinan Risiko & Frekuensi & Dampak & Level \\
\hline 1 & Kerusakan pada hardware & 2 & 3 & Menengah \\
\hline 2 & Overheat & 2 & 3 & Menengah \\
\hline 3 & Overload & 3 & 2 & Rendah \\
\hline 4 & Listrik padam & 5 & 3 & Tinggi \\
\hline 5 & Server down & 5 & 4 & Tinggi \\
\hline 6 & Koneksi internet terputus & 1 & 4 & Tinggi \\
\hline 7 & Kehilangan data & 2 & 5 & Menengah \\
\hline 8 & Kesalahan pegawai/Human Error & 3 & 4 & Menengah \\
\hline 9 & Dokumentasi program kurang lengkap & 1 & 2 & Rendah \\
\hline 10 & Maintenance tidak terjadwal & 2 & 3 & Menengah \\
\hline 11 & Serangan virus & 1 & 4 & Menengah \\
\hline 12 & Penyalahgunaan hak akses & 1 & 4 & Menengah \\
\hline 13 & Pencurian perangkat & 1 & 5 & Menengah \\
\hline 14 & Kebakaran & 2 & 5 & Tinggi \\
\hline 15 & Sambaran petir & 2 & 2 & Menengah \\
\hline 16 & Banjir & 2 & 3 & Menengah \\
\hline 17 & CCTV tidak berfungsi dengan baik & & & \\
\hline 18 & Genset tidak berfungsi dengan baik & & \\
\hline
\end{tabular}

Dari hasil Tabel 5 Evaluasi Risiko, ditemukan bahwa terdapat 3 kemungkinan risiko dengan tingkatan rendah, 11 kemungkinan risiko dengan tingkatan menengah, dan 4 kemungkinan risiko dengan tingkatan tinggi.

\subsection{Perlakuan Risiko}

Perlakuan risiko merupakan tindakan yang diberikan berupa usulan perlakuan dalam menangani risiko yang ada. Berikut tabel perlakuan risiko untuk masing-masing risiko:

Tabel 6. Perlakuan Risiko

\begin{tabular}{|c|l|l|l|}
\hline No & Kemungkinan Risiko & Level & Usulan Perlakuan Risiko \\
\hline 1 & Kerusakan pada hardware & Menengah & $\begin{array}{l}\text { Memberikan tanggung jawab } \\
\text { kepada setiap pegawai agar } \\
\text { menggunakan hardwaresuai } \\
\text { prosedur yang ada Apabila } \\
\text { hardware rusak dan tidak bisa } \\
\text { diperbaiki maka segera mengurus } \\
\text { permintaan hardware baru agar } \\
\text { tidak menghambat aktivitas proses } \\
\text { bisnis. }\end{array}$ \\
\hline 2 & Overheat & Menengah & $\begin{array}{l}\text { Meletakkan hardware sesuai } \\
\text { dengan suhu yang dianjurkan dan } \\
\text { melakukan maintenance secara } \\
\text { terjadwal. }\end{array}$ \\
\hline 3 & Overload & Rendah & $\begin{array}{l}\text { Monitoring server untuk } \\
\text { memastikan dalam keadaan baik, } \\
\text { optimasi gambar, dan juga } \\
\text { memperluas kapasitas bandwidth }\end{array}$ \\
\hline
\end{tabular}

Fachrezi, et., al [Manajemen Risiko Keamanan Aset Teknologi Informasi Menggunakan Iso 31000:2018 Diskominfo Kota Salatiga] 


\begin{tabular}{|c|c|c|c|}
\hline & & & pada website. \\
\hline 4 & Listrik padam & Tinggi & $\begin{array}{l}\text { Sebaiknya genset otomatis } \\
\text { menyala saat listrik padam. }\end{array}$ \\
\hline 5 & Server down & Tinggi & $\begin{array}{l}\text { Monitoring data center dan perlu } \\
\text { adanya maintenance server secara } \\
\text { berkala dan terjadwal. }\end{array}$ \\
\hline 6 & Koneksi internet terputus & Tinggi & $\begin{array}{l}\text { Melakukan pengecekan pada ISP } \\
\text { terkait maupun jaringan yang ada } \\
\text { pada DISKOMINFO Kota } \\
\text { Salatiga. }\end{array}$ \\
\hline 7 & Kehilangan data & Menengah & $\begin{array}{l}\text { Melakukan backup data sesuai } \\
\text { standar dan merubah kata sandi } \\
\text { secara berkala. }\end{array}$ \\
\hline 8 & $\begin{array}{l}\text { Kesalahan pegawai / Human } \\
\text { Error }\end{array}$ & Menengah & $\begin{array}{l}\text { Melakukan pelatihan kepada SDM } \\
\text { berdasarkan standar yang sudah } \\
\text { ditentukan. }\end{array}$ \\
\hline 9 & $\begin{array}{lll}\text { Dokumentasi } & \text { program } & \text { kurang } \\
\text { lengkap } & & \\
\end{array}$ & Menengah & $\begin{array}{l}\text { Menyertakan dokumentasi pada } \\
\text { setiap pengembangan maupun } \\
\text { pembaruan aplikasi. }\end{array}$ \\
\hline 10 & Maintenance tidak terjadwal & Rendah & \begin{tabular}{lrr} 
Melakukan & \multicolumn{2}{c}{ penjadwalan } \\
maintenance dengan baik dan \\
memberikan & informasi \\
maintenance sebelum adanya \\
maintenance, sebaiknya 1 atau 2 \\
hari sebelumnya.
\end{tabular} \\
\hline 11 & Serangan virus & Menengah & $\begin{array}{l}\text { Menyediakan antivirus } \\
\text { melakukan pengecekan } \\
\text { secara berkala pada setiap } \\
\text { perangkat komputer. }\end{array}$ \\
\hline 12 & Penyalahgunaan hak akses & Menengah & $\begin{array}{l}\text { Setiap aktivitas pegawai direkam } \\
\text { untuk tindak pencegahan. Jadi } \\
\text { dalam setiap perubahan data, } \\
\text { terdapat siapa yang melakukan dan } \\
\text { kapan perubahan dilakukan. }\end{array}$ \\
\hline 13 & Pencurian perangkat & Menengah & $\begin{array}{l}\text { Memberikan CCTV pada semua } \\
\text { ruangan. }\end{array}$ \\
\hline 14 & Kebakaran & Menengah & $\begin{array}{l}\text { Menyediakan alarm kebakaran dan } \\
\text { APAR untuk mengantisipasi } \\
\text { terjadinya kebakaran. }\end{array}$ \\
\hline 15 & Sambaran petir & Tinggi & $\begin{array}{l}\text { Memberikan alat penangkal petir } \\
\text { di luar bangunan. }\end{array}$ \\
\hline 16 & Banjir & Menengah & 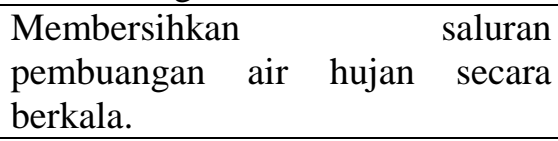 \\
\hline 17 & $\begin{array}{l}\text { CCTV tidak berfungsi dengan } \\
\text { baik }\end{array}$ & Rendah & $\begin{array}{l}\text { Melakukan maintenance secara } \\
\text { berkala. }\end{array}$ \\
\hline 18 & $\begin{array}{l}\text { Genset tidak berfungsi dengan } \\
\text { baik }\end{array}$ & Menengah & $\begin{array}{l}\text { Melakukan maintenance secara } \\
\text { berkala. }\end{array}$ \\
\hline
\end{tabular}

Fachrezi, et., al [Manajemen Risiko Keamanan Aset Teknologi Informasi Menggunakan Iso 31000:2018 Diskominfo Kota Salatiga] 


\section{KESIMPULAN}

Berdasarkan penelitian yang dilakukan di Dinas Komunikasi dan Informatika Kota Salatiga mengenai manajemen risiko keamanan aset menggunakan ISO 31000:2018 dijalankan melalui berbagai tahapan-tahapan yang dimulai dari tahapan penilaian risiko (identifikasi risiko, analisis risiko, dan evaluasi risiko) hingga tahap perlakuan risiko.

Melalui berbagai tahapan tersebut, bahwa telah ditemukan terdapat 2 kemungkinan risiko dengan tingkatan rendah, 11 kemungkinan risiko dengan tingkatan menengah, dan 4 kemungkinan risiko dengan tingkatan tinggi seperti yang tertera pada Tabel 5. Maka dapat disimpulkan bahwa Dinas Komunikasi dan Informatika Kota Salatiga harus melakukan perlakuan risiko untuk meminimalisir terjadi risiko yang akan datang. Terutama pada permasalahan listrik yang sering padam, sebaiknya hal ini diantisipasi dengan genset yang otomatis menyala saat listrik padam.

Proses manajemen risiko pada Dinas Komunikasi dan Informatika Kota Salatiga sudah berjalan dengan baik, namun perlu ditingkatkan lebih dalam. Dengan adanya penelitian ini, diharapkan dapat digunakan sebagai acuan untuk menyusun dokumentasi yang terkait dengan manajemen risiko yang akan datang.

\section{SARAN}

Untuk manajemen risiko pada DISKOMINFO Kota Salatiga, perlu adanya tindakan untuk meminimalisir kemungkinan risiko yang akan terjadi yaitu dengan menindaklanjuti perlakuan risiko dengan baik agar proses bisnis berjalan sesuai dengan yang diharapkan. Dalam penelitian ini, aset yang dituju untuk dilakukan penelitian belum lengkap. Oleh karena itu, saran untuk peneliti di kemudian hari dapat melakukan penelitian dengan cakupan lebih luas dan pemanfaatan IOT (Internet of Things) atau AI (Artifical Intelligence) untuk mencegah, mengambil alih alternatif solusi terhadap risiko, dan untuk menyelesaikan risiko-risiko yang ada. Agar nantinya dapat dimanfaatkan oleh pemangku kepentingan dalam menyusun dokumentasi terkait manajemen risiko sesuai dengan trend saat ini.

\section{UCAPAN TERIMA KASIH}

Terima kasih kepada Tuhan Yang Maha Esa atas segala rahmat yang telah diberikan sehingga penulis dapat dapat menyelesaikan jurnal ini. Penulis mengucapkan terima kasih kepada keluarga, dosen pembimbing, teman kerja praktek, dan narasumber yang telah bersedia untuk melakukan wawancara.

\section{DAFTAR PUSTAKA}

[1] R. M. Candra, Y. N. Sari, I. Iskandar, and F. Yanto. 2019, "Sistem Manajamen Risiko Keamanan Aset Teknologi Informasi Menggunakan ISO 31000 : 2018, ”Vol. 5, No. 1, pp. $19-28$.

[2] K. B. Mahardika, A. F. Wijaya, and D. Cahyono. 2018, "Manajemen Risiko Teknologi Informasi Menggunakan ISO 31000 : 2018 (Studi Kasus: CV. XY),” Vol. 2018, pp. 277284.

Fachrezi, et., al [Manajemen Risiko Keamanan Aset Teknologi Informasi Menggunakan Iso 31000:2018 Diskominfo Kota Salatiga] 
[3] P. Jorion. 2010, “Risk Management," Annu. Rev. Financ. Econ., Vol. 2, pp. 347-365, doi: 10.1146/annurev-financial-073009-104045.

[4] T. Ramdhany and R. A. Krisdiawan. 2018, "Analisis Risiko Sistem Informasi Penjualan Berbasis ISO 31000 - Risk Management Di PT. Remaja Rosdakarya," Teknol. dan Manaj. Inform., Vol. 3, No. 1, pp. 1-7.

[5] D. L. Ramadhan, R. Febriansyah, and R. S. Dewi. 2020, "Analisis Manajemen Risiko Menggunakan ISO 31000 pada Smart Canteen SMA XYZ," JURIKOM (Jurnal Ris. Komputer), Vol. 7, No. 1, p. 91, doi: 10.30865/jurikom.v7i1.1791.

[6] C. A. Mursid and W. Sutopo. 2017, "Manajemen Risiko Dalam Proses Memilih Vendor Menggunakan ISO 31000 dan Analisis Laporan Keuangan: Studi Kasus, ” pp. 8-9.

[7] J. Komputasi. 2020, “Analisis Manajemen Risiko Sistem Informasi Pengelolaan Data English Proficiency Test (EPT) dan Portal Informasi di UPT Bahasa Universitas Lampung Menggunakan Metode ISO 31000, ”Vol. 8, No. 1, pp. 83-90.

[8] Z. Putra et al. 2017, "Desain Manajemen Risiko Berbasis ISO 31000 pada PDAM Tirta Meulaboh,” Vol. III, No. 1, pp. 52-71.

[9] G. W. Lantang, A. D. Cahyono, and N. Ngalumsine, "Analisis Risiko Teknologi Informasi pada Aplikasi Sap di PT. Serasi Autoraya Menggunakan ISO 31000,” pp. 3643. 